\title{
CRIMINAL LIABILITY DAN DIVERSI TERHADAP TINDAK PIDANA ANAK DALAM SISTEM PERADILAN ANAK DI INDONESIA
}

\author{
Sekhroni.* \\ Mahkamah Agung Republik Indonesia \\ Email:sekhroni@gmail.com
}

\begin{abstract}
The author wrote an article titled Criminal Liability And Diversion Crime Against Children in Juvenile Justice System In Indonesia, as for the formulation of research problems are formulated into tititk How Criminal Accountability of children in Juvenile Justice System and Why Diversi applied in the Juvenile Justice System. The purpose of this study was to determine the child's Accountability Criminal Justice System and the Son, Diversi Why applied in the Juvenile Justice System. This research could be useful in a practical and theoretical, in practice, could be used as a practical policy in handling cases of child versioned and can theoretically be a treasury of knowledge of criminal law especially criminal cases involving children. The method used by the researchers is the evaluative method of analysis, which is a method of collecting and presenting data obtained to analyze the actual situation and then do a rational analysis based on the reference of juridical through library research and field research. The results of this study Implementation of mandatory diversion attempted to resolve crimes where the perpetrator is a child. This is a factor cases children rarely even there that are not up to the court so that the juvenile justice exist in the district court to be less effective function, the judges certified judge a child, there is a courtroom especially for children, there is room custody of children but rarely even not at all No trial activities of children.

Keywords: Diversion, Crime Child, Criminal Case
\end{abstract}

\begin{abstract}
Abstrak
Penulis menulis artikel yang berjudul Criminal Liability Dan Diversi Terhadap Tindak Pidana Anak Dalam Sistem Peradilan Anak Di Indonesia, adapun rumusan penelitian yang dirumuskan menjadi tititk permasalahan adalah Bagimana Pertanggung Jawaban Pidana anak dalam Sistem Peradilan Anak dan Mengapa Diversi diterapkan dalam Sistem Peradilan Anak. Adapun tujuan penelitian ini adalah untuk mengetahui Pertanggung Jawaban Pidana anak dalam Sistem Peradilan Anak dan, Mengapa Diversi diterapkan dalam Sistem Peradilan Anak. Penelitian ini dapat berguna secara praktis dan teoritis, secara praktis dapat digunakan sebagai acuan kebijakan praktis dalam penanganan perkara anak secara diversi dan secara teoritis dapat menjadi khasanah ilmu pengetahuan hukum pidana khusunya menyengkut perkara pidanacanak. Metode penelitian yang digunakan oleh peneliti adalah metode evaluative analisis, yaitu suatu metode mengumpulkan dan menyajikan data yang diperoleh untuk menganalisis keadaan yang sebenarnya dan selanjutnya dilakukan analisis rasional berdasarkan
\end{abstract}

- Panitera Muda Pidana di Pengadilan Negeri Tegal, Dosen pada STAIBN Tegal, Mahasiswa Program Doktoral IImu Hukum UNS Surakarta. 
acuan yuridis melalui penelitian kepustakaan dan penelitian lapangan. Hasil penelitian ini Penerapan diversi wajib diupayakan untuk menyelesaikan tindak pidana yang pelakunya adalah anak. Hal ini yang menjadi faktor kasus anak jarang bahkan ada yang tidak sampai ke pengadilan sehingga pengadilan anak yang ada pada pengadilan negeri menjadi kurang efektif fungsinya, ada hakim bersertifikasi hakim anak, ada ruang sidang khusus anak, ada ruang tahanan anak namun jarang bahkan sama sekali tidak ada kegiatan persidangan anak.

Kata kunci : Diversi, Tindak Pidana Anak, Perkara Pidana

\section{A. Pendahuluan}

Berangkat dari keadaan perkara pidana anak di kantor Pengadilan Negeri Brebes dan Pengadilan Negeri Klas I B Tegal serta pengadilan negeri lain menunjukan bahwa perkara pidana yang dilakukan oleh anak yang diserahkan ke pengadilan negeri menurun sangat drastis bahkan sama sekali tidak ada persidangan di ruang sidang anak, meskipun sudah di persiapkan sesuai hukum acara persidangan anak tersebut.

Menurunnya proses persidangan anak di pengadilan negeri dikarenakan telah diberlakukan Undang-Undang Republik Indonesia Nomor 11 Tahun 2012 tentang Sistem Peradilan Pidana Anak (selanjutnya disingkat UU SPPA) yang merupakan pergantian terhadap Undang-undang Nomor 3 Tahun 1997 tentang Pengadilan Anak, telah mengatur secara tegas mengenai Keadilan Restoratif dan Diversi yang dimaksudkan untuk menghindari dan menjauhkan anak dari proses peradilan sehingga dapat menghindari stigma terhadap anak yang berhadapan dengan hukum dan si anak dapat kembali ke dalam lingkungan sosial secara wajar. Oleh karena itu sangat diperlukan peran serta semua pihak dalam mewujudkan hal tersebut.

Dengan diperlakukan Undang Undang Sistem Peradilan Pidana Anak (selanjutnya disingkat UU SPPA) tersebut, ternyata menjadi salah satu faktor utama kasus pelaku anak di proses di pengadilan negeri sehingga 
ruang sidang yang dipersiapkan khusus memeriksa, mengadili dan memutus perkara yang dilakukan oleh anak dan hakim anak dalam hal ini kurang efektif dalam menjalankan roda peradilan anak serta register induk pidana anak, register penahanan pidana anak, register banding pidana anak, register kasasi pidana anak dan register peninjauan kembali pidana anak tercatat nihil.

Merujuk penomena diatas menunjukan bahwa sistem restoratif lebih dikedepankan dalam proses mengadili kesalahan pelaku anak sebagaimana ditentukan Pasal 1 angka 6 UU SPPA disebutkan bahwa Keadilan Restoratif adalah penyelesaian perkara tindak pidana dengan melibatkan pelaku, korban, keluarga pelaku/korban, dan pihak lain yang terkait untuk bersama-sama mencari penyelesaian yang adil dengan menekankan pemulihan kembali pada keadaan semula, dan bukan pembalasan.

Dalam tindak pidana anak, kesalahan dan mampu bertanggung jawab atas perbuatan pidana serta usia masih tergolong anak yang usia dibawah 18 tahun merupakan syarat mutlak pelaku dapat diproses melalui peradilan anak atau melalui lembaga diversi dari tyingkat penyudik, penuntutan sampai tingkat pengadilan. Tanpa adanya kesalahan dan dan mampu bertanggung jawab maksudnya tidak ada alasan pemaaf atau alasan pembenar hal tersebut tidak dapat dikatakan jevenule delequensi.

Unsur yang fondamental mengenai pemidanaan terletak ada dan tidak adanya kesalahan/guilt yang dilakukan oleh subyek yang mampu bertanggung jawab atas hukum. Siapa dan apapun obyek dari tindak pidana tidak akan memiliki makna hukum pidana tanpa adanya subyek 
yang mampu bertanggung jawab atas tindakan tersebut. Hal ini sebagai dasar untuk menentukan diproses atau tidaknya, terletak pada mampu atau tidak pertanggungjawabannya.

Disampaing pelaku anak diversi unsur yang fondamental mengenai pemidanaan terletak ada dan tidak adanya kesalahan/guilt yang dilakukan oleh subyek yang mampu bertanggung jawab atas hukum. Siapa dan apapun obyek dari tindak pidana tidak akan memiliki makna hukum pidana tanpa adanya subyek yang mampu bertanggung jawab atas tindakan tersebut. Hal ini sebagai dasar untuk menentukan diproses atau tidaknya, terletak pada mampu atau tidak dalam pertanggungjawabannya.

Pertanggungjawaban pidana (criminal liability) dalam hukum pidana positif saat ini menganut asas kesalahan (guilt) sebagai salah satu asas disamping asas legalitas. Sistem pertanggungjawaban pidana dalam hukum pidana nasional menerapkanasas tiada pidana tanpa kesalahan yang merupakan salah satu asas fundamental yang perlu ditegaskan secara eksplisit sebagai pasangan asas legalitas. Kedua asas tersebut tidak dipandang syarat yang kaku dan bersifat absolut. Oleh karena itu memberi kemungkinan dalam hal-hal tertentu untuk menerapkan asas strict liability, vicarious liability, erfolgshaftung, kesesatan atau error, rechterlijk pardon, culpa in causa dan pertanggungjawaban pidana yang berhubungan dengan masalah subjek tindak pidana.

Sistem pertanggungjawaban pidana dalam hukum pidana positif saat ini menganut asas kesalahan sebagai salah satu asas disamping asas legalitas. Sistem pertanggungjawaban pidana dalam hukum pidana nasional yang akan datang menerapkan asas tiada pidana tanpa 
kesalahan yang merupakan salah satu asas fundamental yang perlu ditegaskan secara eksplisit sebagai pasangan asas legalitas. Kedua asas tersebut tidak dipandang syarat yang kaku dan bersifat absolut. Oleh karena itu memberi kemungkinan dalam hal-hal tertentu untuk menerapkan asas strict liability, vicarious liability, erfolgshaftung, kesesatan atau error, rechterlijk pardon, culpa in causa dan pertanggungjawaban pidana yang berhubungan dengan masalah subjek tindak pidana. Maka dari itu ada pula ketentuan tentang subjek berupa korporasi. Semua asas itu belum diatur dalam KUHP (Wvs).

Dalam pengertian tindak pidana tidak termasuk pertanggungjawaban pidana. Tindak pidana hanya menunjuk kepada dilarang dan diancamnya perbuatan dengan suatu pidana. Namun orang yang melakukan tindak pidana belum tentu dijatuhi pidana sebagaimana yang diancamkan, hal ini tergantung pada "apakah dalam melakukan perbuatan ini orang tersebut mempunyai kesalahan", yang merujuk kepada asas dalam pertanggungjawaban dalam hukum pidana: " tidak dipidana jika tidak ada kesalahan ". Asas ini memang tidak diatur dalam hukum tertulis tapi dalam hukum tidak tertulis yang juga berlaku di Indonesia.

Dari hal di atas menunjukan dewasa ini terjadi pergeseran ketentuan pidana anak yang awalnya hanya di prioses di lembaga peradilan saja sekarang bisa diselesaikan melalui lembaga restorasi. Hal ini terjawab sudah bahwa hukum itu ada karena ada masyarakat/ sosial, hukum untuk masyarakat sehingga tidak ada hukum dunia yang abadi kecuali hukum tuhan, karena masyarakat itu dinamis sehingga hukumpun akan mengalami perubahan dan masyarakatpun bisa mengalai 
perubahan dengan adannya hukum, : perubahan sosial. Perubahan sosial di dalam kehidupan masyarakat adalah merupakan gejala umum yang terjadi di setiap masyarakat kapan dan di mana saja. Perubahan sosial juga merupakan gejala sosial yang terjadi sepanjang masa. Karena melekatnya gejala perubahan sosial di dalam masyarakat itu, sampai sampai ada yang mengatakan bahwa semua yang ada di masyarakat mengalami perubahan, kecuali satu hal yakni perubahan itu sendiri.

Konsep dan pemikiran tentang Ubi societas Ibi ius yang bermakna dimana ada masyarakat di situ ada hukum, maka perlu digambarkan hubungan antara perubahan sosial dan hukum dalam kaitannya dengan aturan. Masyarakat ada dan menciptakan hukum, masyarakat berubah, maka hukumpun berubah. Perubahan hukum melalui dua bentuk, yakni masyarakat berubah terlebih dahulu, baru hukum datang mengesahkan perubahan itu (perubahan pasif) dan bentuk lain yaitu hukum sebagai alat untuk mengubah ke arah yang lebih baik (law as a tool of sosial engineering).

Peranan hukum di dalam masyarakat khususnya dalam menghadapi perubahan masyarakat perlu dikaji dalam rangka mendorong terjadinya perubahan sosial. Pengaruh peranan hukum ini bisa bersifat langsung dan tidak langsung atau signifikan atau tidak. Hukum memiliki pengaruh yang tidak langsung dalam mendorong munculnya perubahan sosial pada pembentukan lembaga kemasyarakatan tertentu yang berpengaruh langsung terhadap masyarakat. Di sisi lain, hukum membentuk atau mengubah institusi pokok atau lembaga kemasyarakatan yang penting, maka terjadi 
pengaruh langsung, yang kemudian sering disebut hukum digunakan sebagai alat untuk mengubah perilaku masyarakat.

Signifikannya peranan hukum dalam menciptakan perubahan sosial ini kemudian menyebabkan muncul strategi-strategi yang memanfaatkan penciptaan hukum untuk menggiring masyarakat ke arah dan tujuan tertentu. Namun tidak semua peraturan hukum yang dibuat akan serta merta berhasil untuk menciptakan perubahan sosial. Ada berbagai hal yang sangat perlu diperhatikan untuk mengefektifkan suatu legislasi dalam rangka membawa masyarakat ke arah perubahan yang diinginkan oleh pembentuk hukum.

Konsep dan pemikiran tentang Ubi societas Ibi ius yang bermakna dimana ada masyarakat di situ ada hukum, maka perlu digambarkan hubungan antara perubahan sosial dan hukum dalam kaitannya dengan aturan. Masyarakat ada dan menciptakan hukum, masyarakat berubah, maka hukumpun berubah. Perubahan hukum melalui dua bentuk, yakni masyarakat berubah terlebih dahulu, baru hukum datang mengesahkan perubahan itu (perubahan pasif) dan bentuk lain yaitu hukum sebagai alat untuk mengubah ke arah yang lebih baik (law as a tool of sosial engineering)

Berdasarkan uraian tersebut maka akan tampak bahwa anak yang telah melakukan tidak pidana dan mampu bertanggung jawab wajib diselesaikan melalui lembaga diversi lebih dahulu jika lembaga diversi tidak berhasil baru di selesaikan melalui persidangan di pengadilan anak ini yang menyebabkan faktor utama menurunnya kasus anak di pengadilan negeri. Berdasarkan latar belakang tersebut di atas penulis tertarik untuk menulis makalah yang berjudul : Criminal liability dan 
diversi terhadap tindak pidana anak dalam sistem peradilan anak di indonesia

\section{B. Rumusan Masalah}

Berdasarkan uraian dalam latar belakang tersebut di atas maka dapat dirumuskan permasalahan sebagai berikut :

1. Apa Pertanggung Jawaban Pidana anak dalam Sistem Peradilan Anak?

2. Mengapa Diversi diterapkan dalam Sistem Peradilan Anak?

\section{Landasan Teori dan Kerangka Konseptual.}

Fungsi hukum adalah untuk pembaharuan (renew) perilaku masyarakat, maksudnya bahwa hukum harus menjadi instrumen dalam mengarahkan masyarakat untuk menuju kepada tujuan yang diinginkan, bahkan bila perlu, menghilangkan kebiasaan masyarakat yang dipandang negatif. Dengan demikian, artinya ruang lingkup hukum meliputi seluruh aspek kehidupan masyarakat yang ditata oleh hukum. Sebagaimana menurut Roscoe Pound, "bahwa hukum dapat berfungsi sebagai alat untuk pembaharuan masyarakat (law as a tool of social engineering)".

Apa yang harus digarap oleh hukum dalam konteks social engineering itu ? jawabannya adalah "menata kepentingan yang ada dalam masyarakat". Kepentingan-kepentingan tersebut harus ditata sedimikian rupa agar tercapai keseimbangan yang proporsional. Manfaatnya adalah terbangunya suatu struktur masyarakat sedemikian rupa sehingga secara maksimum mencapai kepuasan akan kebutuhan dengan seminimum mungkin menghindari benturan dan pemborosan. Lalu apa sajakah kepentingan-kepentingan dimaksud? Pound mengajukan

${ }^{1}$ Roescoe Pound, 1961, An Introduction to the Philosophy of Law, New Haven, Yale University Press, hal.223 
tiga kategori kelompok kepentingan, yaitu kepentingan umum, sosial, dan kepentingan pribadi. ${ }^{2}$

Sebagai pemikir sociological Jurisprudence, Pound mengusulkan agar para ahli hukum beraliran sisiologis perlu lebih memperhitungkan fakta sosial dalam pekerjaannya, apakah pembuatan hukum, penafsiran, atau penerapan peraturan. Sebab bagi Pound, kehidupan hukum terletak pada pelaksanaanya. Pound menolak studi hukum sebagai studi tentang peraturan, melainkan keluar dari situ dan melihat efek dari hukum dan bekerjanya hukum. Tentang ini, dikatakan oleh Pound : "... to enable and to compel law making, and also interpretation and application of legal rules, to make more account, and more intellegent account, of the social fact upon which law must proceed and to which is to be applied. ${ }^{3}$

Jerome Frank mengatakan bahwa tujuan utama penganut realisme hukum (legal realism) adalah untuk mebuat hukum :"menjadi lebih responsif terhadap kebutuhan sosial" untuk mencapai tujuan ini, mereka mendorong perluasan "bidang-bidang yang memiliki keterkaitan secara hukum". Agar pola pikir atau nalar hukum dapat mencakup pengetahuan di dalam konteks sosial dan memiliki pengaruh terhadap tindakan resmi para aparat hukum. Seperti halnya realisme hukum, sociological juresprudence juga ditunjukan untuk memberi kemampuan bagi institusi hukum, untuk secara lebih menyeluruh dan cerdas mempertimbangkan fakta-fakta sosial di mana hukum itu berproses dan diaplikasikan. Teori Pound mengenai kepentingan-kepentingan sosial

${ }^{2}$ Bernard L. Tanya, Yoan N. Simanjutak, Markus Y. Hage, 2013, Teori Hukum Strategi Tertib Manusia Lintas Ruang dan Generasi, Genta Publishing, Yogyakarta, Hal 140.

${ }^{3}$ Ibid, Hal 145 
merupakan sebuah usaha yang lebih eksplisit untuk mengembangkan suatu model hukum responsif. Dalam presfektif ini, hukum yang baik seharusnya memberikan sesuatu yang lebih daripada sekedar prosedur hukum tersebut harus berkompeten dan juga adil. ${ }^{4}$

Sociological jurisprudence theory di atas diajadikan acuhan dalam menemukan problem yang terjadi dalam pencemaran dan atau perusakan lingkungan hidup dewasa ini. Meskipun sudah disediakan sanksi pidana yang diharapkan mampu untuk mencegah dan membuat jera bagi para pelaku namun kenyataannya tidak memiliki kekuatan untuk menghentikan tindakan pelaku pencemaran dan perusakan lingkungan hidup tersebut.

Dari teori hukum diatas alangkah lebih lengkapnya jika dipahaminya keberadaan hukum itu sendiri dalam masyarakat diperlukan suatu studi dengan pendekatan empirik dengan pendekatan non doktrinal sangat diperlukan adanya pengamatan mengenai peroperasinya hukum yang ada dalam realitas soaial. Dalam kaitan ini hukum dilihat sebagai sistem menurut Lawrence $M$. Friedman bahwa hukum terdiri dari tiga komponen yaitu pertama. Legal substance, yaitu norma-norma atau aturan-aturan yang digunakan secara institusional beserta pola perilaku para pelaku dalam sistem hukum. Kedua, legal structure, yaitu lembagalembaga yang bertugas untuk menegakan hukum, seperti kepolisian, jaksa, hakim, advokat. Dan ketiga legal culture, yaitu kebiasaan, pandangan, cara bertindak dan berpikir dalam masyarakat umum yang

4 Philippe Nonet\&Philip Selznick, 2013, Hukum Responsif Pilihan di Masa Transisi, Perkumpulan Untuk Pembaharuan Hukum Berbasis Masyarakat dan Ekologis (Hu Ma), Jakarta, Hal 59 
dapat mempengaruhi kekuatan-kekuatan sosial menurut arah perkembangan tertentu. ${ }^{5}$

\section{Pembahasan}

Pertanggungjawaban pidana dalam istilah asing tersebut juga dengan teorekenbaardheid atau criminal responsibility yang menjurus kepada pemidanaan petindak dengan maksud untuk menentukan apakah seseorang terdakwa atau tersangka dipertanggung jawabkan atas suatu tindakan pidana yang terjadi atau tidak.

Di dalam penjelasannya dikemukakan: Tindak pidana tidak berdiri sendiri, itu baru bermakna manakala terdapat pertanggungjawaban pidana. Ini berarti setiap orang yang melakukan tindak pidana tidak dengan sendirinya harus dipidana. Untuk dapat dipidana harus ada pertanggungjawaban pidana. Pertanggungjawaban pidana lahir dengan diteruskannya celaan (vewijbaarheid) yang objektif terhadap perbuatan yang dinyatakan sebagai tindak pidana yang berlaku, dan secara subjektif kepada pembuat tindak pidana yang memenuhi persyaratan untuk dapat dikenai pidana karena perbuatannya.

Dalam bahasa Belanda, istilah pertanggungjawaban pidana menurut Pompee terdapat padanan katanya, yaitu aansprakelijk, verantwoordelijk, dan toerekenbaar. Orangnya yang aansprakelijk atau verantwoordelijk, sedangkan toerekenbaar bukanlah orangnya, tetapi perbuatan yang dipertanggungjawaban kepada orang. Biasa pengarang lain memakai istilah toerekeningsvatbaar. Pompee keberatan atas pemakaian istilah yang terakhir, karena bukan orangnya tetapi perbuatan yang toerekeningsvatbaar.

${ }^{5}$ Lawrence L. Friedman, 1986, The Legal system: Social Science Prespektive, New Yoek, Russel Sage Foundation, Hal.17 
Pada umumnya terdapat tiga teori mengenai kesalahan, yaitu 1. Teori psikologis yang menganggap kesalahan sebagai sesuatu yang terdapat dalam alam pemikiran orang yang bersalah (sipelaku) tadi, yang seakan akan dapat ditangkap (dimengerti) oleh hakim, mungkin dengan bantuan seorang psikiater (dokter penyakit jiwa) atau psikoanalis. 2. Teori normatif yang menganggap kesalahan tidak sebagai sesuatu yang terdapat dalam alam pikiran, tetapi sebagai sifat yang sedimikian rupa yang ditentukan oleh pertimbangan hukum (misalnya : penilaian tentang apa yang salah, sehubungan dengan niat orang yang bersalah/ sipelaku tadi. 3. Teori yang dimaksudkan disini, dimana kesalahan dilihat dari segi keputusan pengadilan, yaitu tindakan hukum yang diambil. Tindakan serupa itu harus bersifat tegas seperti mengenakan benda, memasukan orang yang bersalah tersebut kedalam penjara khusus, untuk waktu tertentu atau lembaga sakit jiwa yang dikhususkan dimana ia akan menerima perlakuan khusus, dalam rangka pengobatan jiwa dan pembinaan sifat sosialnya. ${ }^{6}$

Adapun prof. Mr. Roeslan Saleh menulis bahwa dalam pengertian perbuatan pidana tidak termasuk hal pertanggungjawaban. Perbuatan pidana hanya menunjuk kepada dilarangnya perbuatan. Apakah orang yang telah melakukan perbuatan itu kemudian juga dipidana, tergantung pada soal, apakah dia dalam melakukan perbuatan itu mempunyai kesalahan atau tidak. Apabila orang yang dalam melakukan perbuatan pidana itu memang mempunyai kesalahan, maka tentu dia akan dipidana, tetapi manakala dia tidak mempunyai kesalahan, walaupun dia tidak melakukan perbuatan yang terlarang dan tercela, dia tentu tidak Hal.54

6 Soedjono D, Pertanggung-jawaban Dalam Hukum Pidana, Alumni, Bandung, 
dipidana. Asas yang tidak tertulis :"tidak dipidana jika tidak ada kesalahan" merupakan dasar dari pidananya sipembuat. ${ }^{7}$

Kebijakan menetapkan suatu sistem pertanggungjawaban pidana sebagai salah satu kebijakan kriminal merupakan persoalan pemilihan dari berbagai alternatif. Dengan demikian, pemilihan dan penetapan sistem pertanggungjawaban pidana tidak dapat dilepaskan dari berbagai pertimbangan yang rasional dan bijaksana sesuai dengan keadaan dan perkembangan masyarakat

Sehubungan dengan masalah tersebut di atas maka Romli Atmasasmita menyatakan sebagai berikut :

"Berbicara tentang konsep liability atau "pertanggungjawaban" dilihat dari segi falsafat hukum, seorang filosof besar dalam bidang hukum pada abad ke-20, Roscou Pound, dalam An Introduction to the Philosophy of Law, telah mengemukakan pendapatnya "I .... Use the simple word "liability" for the situation whereby one exact legally and other is legally subjected to the exaction.

Bertitik tolak pada rumusan tentang "pertanggungjawaban" atau liability tersebut diatas, Pound membahasnya dari sudut pandang filosofis dan sistem hukum secara timbal balik. Secara sistematis, Pound lebih jauh menguraikan perkembangan konsepsi liability. Teori pertama, menurut Pound, bahwa liability diartikan sebagai suatu kewajiban untuk membayar pembalasan yang akan diterima pelaku dari seseorang yang telah "dirugikan". Sejalan dengan semakin efektifnya perlindungan undang-undang terhadap

7 Prof. Mr. Roeslan Saleh, 1981, Perbuatan Pidana dan Pertanggungan Jawab Pidana, Aksara Baru, jakarta, Hal.80 
kepentingan masyarakat akan suatu kedamaian dan ketertiban, dan adanya keyakinan bahwa "pembalasan" sebagai suatu alat penangkal, maka pembayaran "ganti rugi" bergeser kedudukannya, semula sebagai suatu "hak istimewa" kemudian menjadi suatu "kewajiban". Ukuran "ganti rugi" tersebu tidak lagi dari nilai suatu pembalasan yang harus "dibeli", melainkan dari sudut kerugian atau penderitaan yang ditimbulkan oleh perbuatan pelaku yang bersangkutan.

Dalam hukum pidana juga memperhatikan orangnya, dalam hal ini dibicarakan kesalahan orang sebagai pelaku, atau orang tersebut perbuatannya harus dapat dipertanggungjawabkan secara pidana, untuk nantinya dijatuhi suatu pidana. Dalam hal ini berlaku asas hukum pidana tiada pidana tanpa kesalahan (nulla poena sine culpa). Sehubungan dengan perkembangan masyarakat, yang bertanggung jawab dalam hukum pidana tidak hanya orang (dalam arti manusia), namun juga korporasi. $^{8}$

Pembicaraan mengenai pertanggungjawaban pidana tidak dapat dilepaskan dari pembicaraan mengenai perbuatan pidana. Orang tidak mungkin dipertanggungjawabkan untuk dipidana, apabila ia tidak melakukan tindak pidana. Para penulis sering menggambarkan bahwa dalam menjatuhkan pidana unsur " tindak pidana" dan "pertanggungjawaban pidana" harus dipenuhi.

Unsur tindak pidana dan kesalahan (kesengajaan) adalah unsur yang sentral dalam hukum pidana. Unsur perbuatan pidana terletak dalam lapangan objektif yang diikuti oleh unsur sifat melawan hukum, sedangkan unsur pertanggungjawaban pidana merupakan

8 Prof. Supanto, 2015, Kebijakan Formulasi Hukum Pidana Ekonomi dalam Menghadapi Perkembangan Globalisasi Ekonomi, UNS Press, Hal. 232. 
unsur subjektif yang terdiri dari kemampuan bertanggung jawab dan adanya kesalahan (kesengajaan dan kealpaan).

Pompe menyingkat bahwa kesalahan itu dengan dapatnya dicela (verwijtbaarheid) dan dapat dihindari (vermijdbaarheid) perbuatan yang dilakukan, Dikatakannya "menurut akibat dari hal ini adalah dapat dicela, pada hakikatnya dia adalah dapat dihindarinya kelakuan yang melawan hukum itu, karena kehendak si pembuat terlihat pada kelakuan yang bersifat melawan hukum, maka ini ini dapat dicelakan padanya. ${ }^{9}$

Simons berpendapat mengenai kesalahan adalah keadaan psikis orang yang melakukan perbuatan dan hubungannya dengan perbuatan yang dilakukan, yang sedemikian rupa sehingga orang itu dapat dicela karena perbuatannya. Dalam menentukan bahwa seseorang itu bersalah Atau tidak harus diperhatikan:

1. Keadaan batin dari orang yang melakukan perbuatan.

2. Hubungan antara keadaan batin itu dengan perbuatan yang dilakukan.

Mengenai hal diatas bahwa yang pertama mengatakan mengenai keadaan bathin dari orang yang melakukan pidana, dalam ilmu hukum pidana merupakan hal yang biasa dikatakan dalam pertanggungjawaban hukum, mengenai hal yang kedua yaitu hubungan antara bathin itu dengan perbuatan yang dilakukan merupakan masalah kesengajaan, kealpaan, sehingga mampu bertanggungjawab, mempunyai kesengajaan atau kealpaan serta tidak adanya alasan pemaaf merupakan unsurunsur dari kesalahan.

\footnotetext{
${ }^{9}$ Prof. Mr. Roeslan Saleh, Op.Cit, Hal.82.
} 
Mengenai mampu bertanggung jawab, pada waktu kitab undangundang disusun telah ditetapkan, bahwa unsur ini harus ada untuk dapat dipidananya seorang pelaku. Jika terjadi suatu kekecualian, bahwa seorang pelaku harus dianggap tidak mampu bertanggung jawab, jadi perbuatan itu tak dapat dipertanggungjawabkan padanya, ia akan dilepaskan dari seluruh tuntutan hukum. Pada tahun tahun sesudah kitab undang-undang disahkan, telah berkembang unsur lain, yaitu kesalahan dalam arti disesalkan dan melawan hukum. Pembuat undangundang dalam unsur kesalahan, seperti juga dalam unsur mampu bertanggung jawab, bertolak dari peristiwa biasa. Pembuat undangundang berpendapat, bahwa jika seseorang melakukan kejahatan, kejahatan ini juga akan dapat disesalkan padanya. ${ }^{10}$

Dengan adanya aturan yang berhubungan dengan kemampuan bertanggung jawab seperti dirumuskan dalam Pasal 44 KUHP, yang hanya mengenai ketidakmampuan bertanggung jawab karena jiwa yang cacat dalam tubuhnya atau terganggu karena penyakit, maka akibatnya kalau tidak mampu mempertanggungjawabnya yang melakukan perbuatan karena jiwa yang sangat muda, pasal tersebut tidak dapat dipakai, sehingga harus memakai dasar yang lebih luas yaitu asas yang tidak tertulis : tidak dipidana jika tidak ada kesalahan. Jokers, disamping umur yang sangat muda, masih menyebut : berbuat di bawa hipnotis dan slaapdronkenheid. Biasanya menurut praktik, dalam kedua

${ }^{10}$ Mr. J.M.Van Bemmelen, Hukum Pidana I Hukum Pidana material Bagian Umum, Binacipta, Indonesia, Hal.100 
hal diatas ini, lebih senang dikatakan bahwa tidak ada kesengajaan, sebab apa yang dilakukan memang tidak diinsafi. ${ }^{11}$

Dari hal-hal diatas, bahwa perbuatan pidana yang mampu bertanggung jawabkan maka pelaku dikenai sanksi pidana sebagaimana dalam ketentuan KUHP Hukuman pokok telah ditentukan dalam pasal 10 KUHP yang berbunyi sebagai berikut: Pidana terdiri atas:

a. Pidana Pokok:

1.Pidana Mati

2.Pidana penjara

3.Kurungan

4.Denda

b. Pidana Tambahan:

1.Pencabutan hak-hak tertentu

2.Perampasan barang-barang tertentu

3.Pengumuman putusan hakim

Berkaitan tindak pidana yang pelakunya anak hal tersebut dapat diselesaikan di luar pengadilan dalam sistem restorasi, dalam artian bukan wajib diperiksa, diadili dan diputus oleh hakim anak namun diputus dalam lembaga diversi dalam tingkatan proses penyelesainnya, jika perkaranya ada pada penyidik kepolisian maka bisa diselesaikan ditingkat penyidik tersebut dan seterusnya di tingkat penuntutan oleh penuntut umum demikian juga di pengadilan oleh hakim.

Adapun yang dimaksud pelaku anak sebagaimana ditentukan dalam Pasal 1 angka 1 Undang - Undang No. 23 tahun 2002 tentang Perlindungan anak, pengertian anak adalah seseorang yang belum

11 Prof. Moeljatno, 2008, Asas-Asas Hukum Pidana, Binreka Cipta, Jakarta, Hal.181 
berusia 18 (delapan belas) tahun termasuk anak yang masih dalam kandungan. Sedangkan dalam Konvensi Hak - hak Anak, anak adalah setiap manusia yang berusia di bawah 18 (delapan belas) tahun, kecuali berdasarkan yang berlaku bagi anak tersebut ditentukan bahwa usia dewasa dicapai lebih awal. Sementara itu dalam UU No. 39 tahun 1999 tentang Hak Asasi Manusia, Anak adalah setiap manusia yang berusia di bawah 18 (delapan belas) tahun dan belum menikah termasuk anak yang masih dalam kandungan apabila hal tersebut adalah demi kepentingannya.

Menurut ketentuan Pasal 7 UU SPPA, Diversi hanya dapat dilaksanakan kepada anak yang diancam dengan pidana penjara di bawah 7 (tujuh) tahun, dan bukan merupakan pengulangan tindak pidana (residive). Hal ini sangat perlu diperhatikan untuk memperkecil potensi pemaksaan dan intimidasi pada semua tahap proses diversi. Seorang anak tidak boleh merasa tertekan atau ditekan agar menyetujui program-program diversi. Kesepakatan Diversi harus mendapatkan persetujuan korban dan/atau keluarga Anak Korban serta kesediaan Anak dan keluarganya, kecuali untuk tindak pidana yang berupa pelanggaran, tindak pidana ringan, tindak pidana tanpa korban, atau nilai kerugian korban tidak lebih dari nilai upah minimum provinsi setempat.

Terkait penerapannya dalam pemeriksaan dipersidangan diatur dalam pasal 52 UU SPPA yang menyebutkan:

1. Ketua pengadilan wajib menetapkan Hakim atau majelis hakim untuk menangani perkara Anak paling lama 3 (tiga) hari setelah menerima berkas perkara dari Penuntut Umum. 
2. Hakim wajib mengupayakan Diversi paling lama 7 (tujuh) hari setelah ditetapkan oleh ketua pengadilan negeri sebagai Hakim.

3. Diversi sebagaimana dimaksud pada ayat (2) dilaksanakan paling lama 30 (tiga puluh) hari.

4. Proses Diversi dapat dilaksanakan di ruang mediasi pengadilan negeri.

5. Dalam hal proses Diversi berhasil mencapai kesepakatan, Hakim menyampaikan berita acara Diversi beserta kesepakatan Diversi kepada ketua pengadilan negeri untuk dibuat penetapan.

6. Dalam hal Diversi tidak berhasil dilaksanakan, perkara dilanjutkan ke tahap persidangan.

Mencermati pengaturan tentang penerapan diversi diatas menarik untuk dibahas beberapa hal sebagai berikut :

\section{Pemanggilan untuk pelaksanaan Diversi}

Dalam ayat (2) ditentukan bahwa "Hakim wajib mengupayakan Diversi paling lama 7 (tujuh) hari setelah ditetapkan oleh ketua pengadilan negeri sebagai Hakim". Dengan demikian maka pada saat berkas perkara diterima oleh hakim anak, maka dalam tenggang waktu 7 (tujuh) hari harus segera melaksanakan Diversi. Hal ini membawa konsekuensi bahwa hakim selekas mungkin menetapkan hari Diversi dan didalam penetapan hari diversi agar memerintahkan Penuntut Umum untuk menghadirkan Anak, Orang tua/wali, Penasihat Hukum, Anak Korban, Orang Tua/Wali korban, Petugas Pembimbing Kemasyarakatan, Pekerja Sosial, Tenaga Kesejahteraan Sosial, Perwakilan Masyarakat (RT/RW/Kepala Desa/Tokoh 
Masyarakat/Agama). Sedangkan untuk saksi-saksi lainnya dipanggil kemudian jika Diversi gagal dan persidangan dilanjutkan.

Kehadiran korban pada saat sidang pertama adalah untuk kepentingan pelaksanaan Diversi, bukan untuk didengar keterangannya dipersidangan sebagai saksi korban sebagaimana pemeriksaan perkara pidana umumnya dalam tahap pembuktian. Oleh karena itu apabila pada sidang pertama pihak-pihak yang dipanggil diatas telah hadir maka hakim anak dapat langsung melaksanakan diversi hingga terhitung paling lama 30 (tiga puluh) hari kedepan. Pelaksanaan diversi dapat dilaksanakan di ruang mediasi Pengadilan Negeri tersebut.

\section{Mengenai Penahanan}

Selanjutnya terkait dengan penahanan, apakah dalam proses diversi penahanan terhadap anak tetap diperhitungkan?, karena jika demikian maka masa penahanan akan habis dan Anak dapat dikeluarkan demi hukum. Jawabannya tentu tidak!, karena berdasakan ketentuan pasal 7 UU SPPA secara limitatif telah ditentukan bahwa diversi hanya dapat diterapkan kepada anak yang diancam dengan pidana penjara di bawah 7 (tujuh) tahun dan bukan merupakan pengulangan tindak pidana (residive). Ketentuan tersebut apabila dihubungkan dengan syarat penahanan terhadap anak yang diatur didalam pasal 32 ayat (1) dan ayat (2) yang menyebutkan bahwa :

a. Penahanan terhadap Anak tidak boleh dilakukan dalam hal Anak memperoleh jaminan dari orang tua/Wali dan/atau lembaga bahwa Anak tidak akan melarikan diri, tidak akan menghilangkan 
atau merusak barang bukti, dan/atau tidak akan mengulangi tindak pidana.

b. Penahanan terhadap Anak hanya dapat dilakukan dengan syarat sebagai berikut:

1) Anak telah berumur 14 (empat belas) tahun atau lebih; dan

2) Diduga melakukan tindak pidana dengan ancaman pidana penjara 7 (tujuh) tahun atau lebih.

Dengan demikian jika kembali pada persoalan terkait proses Diversi dan penahanan, maka dapat dipastikan bahwa proses Diversi hanya dapat dilakukan terhadap Anak yang tidak ditahan, karena Anak yang dapat ditahan adalah yang diduga melakukan tindak pidana yang diancam dengan pidana penjara 7 (tujuh) tahun atau lebih, sedangkan proses Diversi hanya diterapkan terhadap Anak yang diancam dengan pidana penjara dibawah 7 (tujuh) tahun.

Hal lainnya yang dapat saja terjadi adalah sebagaimana yang diatur didalam pasal 3 PERMA No. 4 Tahun 2014 Tentang Pedoman Pelaksanaan Diversi Dalam Sistem Peradilan Pidana Anak menyebutkan bahwa hakim anak wajib mengupayakan diversi dalam hal anak didakwa melakukan tindak pidana yang diancam dengan pidana penjara dibawah 7 (tujuh) tahun dan didakwa pula dengan tindak pidana yang diancam dengan pidana penjara 7 (tujuh) tahun atau lebih dalam bentuk surat dakwaan subsidaritas, alternatif, kumulatif, maupun kombinasi (gabungan). Misalnya dakwaan subsidaritas Primair : Pasal 354 ayat (1) KUHP (ancaman penjara 8 tahun), Subsidair : Pasal 351 ayat (2) KUHP (ancaman penjara 5 
tahun), Lebih Subsidair: Pasal 351 ayat (1) KUHP (ancaman penjara 2 tahun 8 bulan).

Pertanyaan yang timbul adalah bagaimana dengan penahanannya?, karena pasal yang didakwakan memenuhi syarat penahanan, sedangkan disisi lain diversi wajib dilaksanakan. Hal ini tidak diatur lebih lanjut didalam PERMA, namun demikian karena diversi wajib dilaksanakan, maka dalam pemeriksaan dipersidangan hakim dapat menggunakan kewenangannya untuk tidak melakukan penahanan terhadap anak.

\section{Jangka Waktu Pelaksanaan Diversi}

Mengenai jangka waktu pelaksanaan Diversi dipersidangan, diatur dalam Pasal 53 UU SPPA yang menyebutkan bahwa diversi sebagaimana dimaksud pada ayat (2) dilaksanakan paling lama 30 (tiga puluh) hari. Dalam prakteknya, bisa saja setelah lewat 30 (tiga puluh) hari atau setelah persidangan berlangsung ternyata pihak korban dan Anak memperoleh kesepakatan untuk berdamai, bagaimana sikap hakim terhadap hal itu?. Menurut Penulis, hakim terlebih dahulu melihat bentuk perdamaian yang dibuat, jikalau sifatnya hanya memaafkan kesalahan Anak namun menginginkan proses hukum tetap berjalan, maka sikap hakim adalah tetap melanjutkan persidangan. Adapun pemberian maaf dari korban/keluarganya akan dipertimbangkan sebagai hal-hal yang meringankan Anak dalam menjatuhkan hukumannya. Apabila dalam perdamaiannya pihak korban meminta agar proses pemeriksaan perkaranya dihentikan, maka adalah lebih bijak jika perkara tersebut dihentikan oleh hakim dan hakim menyampaikan Berita 
Acara Diversi beserta Kesepakatan Diversi kepada Ketua Pengadilan Negeri untuk diterbitkan Penetapan. Hal ini kiranya sejalan dengan jiwa UU SPPA yang megendepankan restoratif justice melalui diversi.

\section{Penetapan Ketua Pengadilan Negeri Mengenai Hasil Diversi}

Hal lainnya yang menarik untuk dibahas adalah mengenai Penetapan Ketua Pengadilan Negeri mengenai hasil Diversi. Hal ini diatur dalam pasal 12 yang menyebutkan bahwa:

a. Hasil kesepakatan sebagaimana dimaksud dalam Pasal 11 dituangkan dalam bentuk kesepakatan Diversi.

b. Hasil kesepakatan Diversi sebagaimana dimaksud pada ayat (1) disampaikan oleh atasan langsung pejabat yang bertanggungjawab di setiap tingkat pemeriksaan ke pengadilan negeri sesuai dengan daerah hukumnya dalam waktu paling lama 3 (tiga) hari sejak kesepakatan dicapai untuk memperoleh penetapan.

c. Penetapan sebagaimana dimaksud pada ayat (2) dilakukan dalam waktu paling lama 3 (tiga) hari terhitung sejak diterimanya kesepakatan Diversi.

d. Penetapan sebagaimana dimaksud pada ayat (3) disampaikan kepada Pembimbing Kemasyarakatan, Penyidik, Penuntut Umum, atau Hakim dalam waktu paling lama 3 (tiga) hari sejak ditetapkan.

e. Setelah menerima penetapan sebagaimana dimaksud pada ayat (4), Penyidik menerbitkan penetapan penghentian penyidikan 
atau Penuntut Umum menerbitkan penetapan penghentian penuntutan.

Faktor-faktor yang menjadi penyebab kenakalan anak di Indonesia.Menurut psikologi, remaja adalah suatu periode transisi dari masa awal anak anak hingga masa awal dewasa, yang dimasuki pada usia kira kira 10 hingga 12 tahun dan berakhir pada usia 18 tahun hingga 22 tahun. Masa remaja bermula pada perubahan fisik yang cepat, pertambahan berat dan tinggi badan yang dramatis, perubahan bentuk tubuh, dan perkembangan karakteristik seksual seperti pembesaran buah dada, perkembangan pinggang dan kumis, dan dalamnya suara. Pada perkembangan ini, pencapaian kemandirian dan identitas sangat menonjol (pemikiran semakin logis, abstrak, dan idealistis) dan semakin banyak menghabiskan waktu di luar keluarga. Sehingga yang terjadi adalah kenakalan remaja.

Adapun faktor yang menyebabkan terjadinya kenakalan remaja secara umum dapat dikelompokan ke dalam dua faktor, yaitu sebagai berikut:

1. Faktor Intern

a. Faktor Kepribadian, Kepribadian adalah suatu organisasi yang dinamis pada system psikosomatis dalam individu yang turut menentukan caranya yang unik dalam menyesuaikan dirinya dengan lingkungannya (biasanya disebut karakter psikisnya). Masa remaja dikatakan sebagai suatu masa yang berbahaya. Pada periode ini, seseorang meninggalkan masa anak-anak untuk menuju masa dewasa. Masa ini di rasakan 
sebagai suatu Krisis identitas karena belum adanya pegangan, sementara kepribadian mental untuk menghindari timbulnya kenakalan remaja atau perilaku menyimpang.

b. Faktor Kondisi Fisik, Faktor ini dapat mencakup segi cacat atau tidaknya secara fisik dan segi jenis kelamin. Ada suatu teori yang menjelaskan adanya kaitan antara cacat tubuh dengan tindakan menyimpang (meskipun teori ini belum teruji secara baik dalam kenyataan hidup). Menurut teori ini, seseorang yang sedang mengalami cacat fisik cenderung mempunyai rasa kecewa terhadap kondisi hidupnya. Kekecewaan tersebut apabila tidak disertai dengan pemberian bimbingan akan menyebabkan si penderita cenderung berbuat melanggar tatanan hidup bersama sebagai perwujudan kekecewaan akan kondisi tubuhnya.

c. Faktor Status dan Peranannya di Masyarakat, Seseorang anak yang pernah berbuat menyimpang terhadap hukum yang berlaku, setelah selesai menjalankan proses sanksi hukum (keluar dari penjara), sering kali pada saat kembali ke masyarakat status atau sebutan "eks narapidana" yang diberikan oleh masyarakat sulit terhapuskan sehingga anak tersebut kembali melakukan tindakan penyimpangan hukum karena meresa tertolak dan terasingkan.

\section{Faktor Ekstern}


a. Kondisi Lingkungan Keluarga, hususnya di kota-kota besar di Indonesia, generasi muda yang orang tuanya disibukan dengan kegiatan bisnis sering mengalami kekosongan batin karena bimbingan dan kasih sayang langsung dari orang tuanya sangat kurang. Kondisi orang tua yang lebih mementingkan karier daripada perhatian kepada anaknya akan menyebabkan munculnya perilaku menyimpang terhadap anaknya. Kasus kenakalan remaja yang muncul pada keluarga kaya bukan karena kurangnya kebutuhan materi melainkan karena kurangnya perhatian dan kasih sayang orang tua kepada anaknya.

b. Kontak Sosial dari Lembaga Masyarakat Kurang Baik atau Kurang Efektif, Apabila system pengawasan lembaga-lembaga sosial masyarakat terhadap pola perilaku anak muda sekarang kurang berjalan dengan baik, akan memunculkan tindakan penyimpangan terhadap nilai dan norma yang berlaku. Misalnya, mudah menoleransi tindakan anak muda yang menyimpang dari hukum atau norma yang berlaku, seperti mabuk-mabukan yang dianggap hal yang wajar, tindakan perkelahian antara anak muda dianggap hal yang biasa saja. Sikap kurang tegas dalam menangani tindakan penyimpangan perilaku ini akan semankin meningkatkan kuantitas dan kualitas tindak penyimpangan di kalangan anak muda.

c. Kondisi Geografis atau Kondisi Fisik Alam, Kondisi alam yang gersang, kering, dan tandus, dapat juga menyebabkan terjadinya tindakan yang menyimpang dari aturan norma yang berlaku, lebih-lebih apabila individunya bermental negative. Misalnya, 
melakukan tindakan pencurian dan mengganggu ketertiban umum, atau konflik yang bermotif memperebutkan kepentingan ekonomi.

d. Faktor Kesenjangan Ekonomi dan Disintegrasi Politik, Kesenjangan ekonomi antara orang kaya dan orang miskin akan mudah memunculkan kecemburuan sosial dan bentuk kecemburuan sosial ini bisa mewujudkan tindakan perusakan, pencurian, dan perampokan. Disintegrasi politik (antara lain terjadinya konflik antar partai politik atau terjadinya peperangan antar kelompok dan perang saudara) dapat mempengaruhi jiwa remaja yang kemudian bisa menimbulkan tindakan-tindakan menyimpang.

e. Faktor Perubahan Sosial Budaya yang Begitu Cepat (Revolusi), Perkembangan teknologi di berbagai bidang khususnya dalam teknologi komunikasi dan hiburan yang mempercepat arus budaya asing yang masuk akan banyak mempengaruhi pola tingkah laku anak menjadi kurang baik, lebih-lebih anak tersebut belum siap mental dan akhlaknya, atau wawasan agamanya masih rendah sehingga mudah berbuat hal-hal yang menyimpang dari tatanan nilai-nilai dan norma yang berlaku.

Merujuk pada hal di atas, bahwa penerapan diversi wajib diupayakan untuk menyelesaikan tindak pidana yang pelakunya adalah anak hal ini yang menjadi faktor kasus anak jarang bahkan ada yang tidak sampai ke pengadilan sehingga pengadilan anak yang ada pada pengadilan negeri menjadi kurang efektif fungsinya, ada hakim bersertifikasi hakim anak, ada ruang sidang khusus anak, ada 
ruang tahanan anak namun jarang bahkan sama sekali tidak ada kegiatan persidangan anak. Dalam bidang administrasi perkara, ada register induk pidana anak, register tahanan anak, register upaya hukum anak seperti register banding anak, register kasasi anak, register grasi anak dan register peninjauan kembali anak tercatat berkurang drastis bahkan ada yang tercatat nihil.

D. Penutup

\section{Simpulan}

Penerapan diversi wajib diupayakan untuk menyelesaikan tindak pidana yang pelakunya adalah anak. Hal ini yang menjadi faktor kasus anak jarang bahkan ada yang tidak sampai ke pengadilan sehingga pengadilan anak yang ada pada pengadilan negeri menjadi kurang efektif fungsinya, ada hakim bersertifikasi hakim anak, ada ruang sidang khusus anak, ada ruang tahanan anak namun jarang bahkan sama sekali tidak ada kegiatan persidangan anak.

\section{Saran.}

Seyogyannya peraturan mengenai diversi terhadap pelaku yang masih tergolong anak, menentukan hanya lembaga peradilan saja yang berwenang untuk penyelenggaraan proses diversi.

\section{Daftar Pustaka}

\section{A. Buku-Buku}

Bernard L. Tanya, Yoan N. Simanjutak, Markus Y. Hage, 2013, Teori Hukum Strategi Tertib Manusia Lintas Ruang dan Generasi, Genta Publishing, Yogyakarta. 
Lawrence L. Friedman, 1986, The Legal system: Social Science Prespektive, New Yoek, Russel Sage Foundation.

Mr. J.M.Van Bemmelen, Hukum Pidana I Hukum Pidana material Bagian Umum, Binacipta, Indonesia.

Moeljatno, 2008, Asas-Asas Hukum Pidana, Binreka Cipta, Jakarta.

Philippe Nonet\&Philip Selznick, 2013, Hukum Responsif Pilihan di Masa Transisi, Perkumpulan Untuk Pembaharuan Hukum Berbasis Masyarakat dan Ekologis (Hu Ma), Jakarta.

Roescoe Pound, 1961, An Introduction to the Philosophy of Law, New Haven, Yale University Press.

Roeslan Saleh, 1981, Perbuatan Pidana dan Pertanggungan Jawab Pidana, Aksara Baru, Jakarta.

Soedjono D, Pertanggung-jawaban Dalam Hukum Pidana, Alumni, Bandung.

Supanto, 2015, Kebijakan Formulasi Hukum Pidana Ekonomi dalam Menghadapi Perkembangan Globalisasi Ekonomi, UNS Press.

\section{B. Peraturan Perundang-Undangan.}

Kitab Undang-Undang Hukum Pidana

Undang-Undang Republik Indonesia Nomor 11 Tahun 2012 tentang Sistem Peradilan Pidana Anak

UU No. 39 tahun 1999 tentang Hak Asasi Manusia

PERMA No. 4 Tahun 2014 Tentang Pedoman Pelaksanaan Diversi Dalam Sistem Peradilan Pidana Anak. 